\title{
IS THERE AN EQUITY-EFFICIENCY TRADE-OFF IN SCHOOL FINANCE? TIEBOUT AND A THEORY OF THE LOCAL PUBLIC GOODS PRODUCER
}

Caroline M. Hoxby

Working Paper 5265

\section{NATIONAL BUREAU OF ECONOMIC RESEARCH 1050 Massachusetts Avenue \\ Cambridge, MA 02138 \\ September 1995}

I am grateful to James Poterba and Jean Tirole for initial conversations about this topic. This research was ably assisted by Anis Shivani. All errors are my own. This paper is part of NBER's research program in Public Economics. Any opinions expressed are those of the author and not those of the National Bureau of Economic Research.

(C) 1995 by Caroline M. Hoxby. All rights reserved. Short sections of text, not to exceed two paragraphs, may be quoted without explicit permission provided that full credit, including $(\mathcal{O}$ notice, is given to the source. 


\title{
IS THERE AN EQUITY-EFFICIENCY TRADE-OFF IN SCHOOL FINANCE? TIEBOUT AND A THEORY OF THE LOCAL PUBLIC GOODS PRODUCER
}

\begin{abstract}
New empirical work shows that the degree of competition among public providers of local public goods or between public and private providers of local public goods matters. This evidence needs a theory of the local public goods producer. Tiebout's hypothesis spawned a literature that gives local public economics a useful theory of the consumer, and the same Tiebout mechanism can generate a theory of the local public goods producer. This potential has remained largely undeveloped apart from Tiebout's vision of the local public goods producer as an entrepreneur, which is unrealistic because local public goods are nonverifiable. The Tiebout mechanism does not operate in alternative models of the local public goods producer, such as bureaucracy and agenda models. None of these models is useful for predicting how local public goods producers react to policies, like school spending equalization, that change the structure of local public finance. This paper builds a theory of the producer that draws upon Tiebout's mechanism and the theory of incentives for regulation. The essential insight is that Tiebout's mechanism generates information that can be used in regulatory schemes to achieve lower costs for any given provision of local public goods. Thus, we face a fundamental trade-off between promoting equitable consumption of the public good and promoting efficiency (cost minimization) in production of the public good. This trade-off exists even when equity in consumption generates positive externalities, as is often suggested of the consumption of schooling. I present evidence that when the Tiebout mechanism for schools is weakened by state-level school funding, per-pupil costs rise and the growth of educational attainment falls. This latter fact implies that losses from inefficient production generally outweigh gains from equalized consumption.
\end{abstract}

Caroline M. Hoxby

Department of Economics

Harvard University

Cambridge, MA 02138

and NBER 


\section{Introduction}

The motivation for this paper is the burgeoning literature about competition among public providers of local public gonds or between public providers of local public goods and private suppliers of the same goods.' This literature is empirical, and has revealed the scantness of our understanding of the prodin $r$ side of local public economics. The consumer side of local pubiic economics, however, has ieen intensely analyzed from Tiebout (1956) Gıwards. The imbalance between the producer and consumer sides has left us with a new empirical literature that asserts the importance of giving good incentives to producers of local public goods while the vast bulk of existing theoretical and empirical work ignores this issue and focuses exclusively on the allocalıu cf local public goods among consumers. We know from private goods that we cusnot generally neglect the producer-side implications of an allocation--in fact, these implications are typically very important to growth. By proposing a useful model of the local public goods producer, this paper attempts to help redress the balance.

Tiebout's (1956) paper effectively allowed local public economics to tap into the theory of the consumer by proposing a mechanism that allows choice over public goods to mimic choice over private goods. The basic mechanism--"voting with the feet" has been contested $;$ - $d$ accordingly refined, but always with the goal of determining whether the Tiebout hypothesis guarantees allocative efficiency. ${ }^{2}$ However, the Tiebout mechanism also leads to a theory of the local public goods producer because consumer choice implies that some producers will not attract any "customers" and will be driven out of the market. In fact, under Tiebout's stringent assumption of costless entry into local public goods production, we are driven towards his model

\footnotetext{
1 See Hoxby (1994a,b), Schleifer et al (1995),

2 Rubinfeld (1987) provides a very useful survey.
} 
of the local public goods producer as a cost-minimizing entrepreneur who steps in to offer a new jurisdiction at a marginally lower price to any group of consumers whose current jurisdiction is earning rent.

Even if consumer choice among jurisdictions is extremely responsive, the entrepreneurial model of the local public goods producer fails because it implicitly requires that local pu' $: \because$ : goods not only be observable to consumers but legally verifiable. This failure, discusseu in more detail below, means that we cannot simply derive cost minimization from an entrepreneurial model. Unfortunately, other models of the local public goods producer do not take the Tiebout mechanism into account at all. Bureaucratic models, which suggest that the producer maximizes his budget or his staff, break down under the pressure of consumer choice. This is true even of models in which a bureaucrat's actions are constrained by voters.

The lack of a realistic theory of the local public goods producer seriously limits our ability to correctly predict the effects of policies that change incentives for local public goods producers. Examples of such policies are school spending equalization, vouchers for private schools, competitive bidding to provide local public goods such as garbage collection, and financing local public goods with in income-based tax rather than a property-based tax. Ox:ng to our inability to describe how these policies should affect the efficiency of local public goods production, past work has focused almost exclusively on predicting the allocative implications of such policies.

In this paper, I attempt to build a useful theory of the local public goods producer--for concreteness, a public school district. The school is regulated by a school board, but the board does not directly observe the school's efforts to minimize costs and provide quality. Instead, the board must make inferences about these efforts from realized costs and enrollment. The 
essential insight is that when the Tiebout mechanism functions, the board has more instruments than he does when policies such as funding equalization dampen the mechanism. The board can use the additional instruments to intensify the incentives to minimize costs without sacrificing incentives to provide quality schooling. In contrast, when the Tiebout mechanism does not function, any incentives the iudrd gives to minimize costs crowd out school quality. Therefore, school districts that function in Tiebout environments produce any given quality of schooling for a lower cost.

This model translates readily into reality. I demonstrate that "traditional" school finance, where local property taxes generate revenue for school expenditure, is an incentive scheme that uses all of the instruments generated by the Tiebout process. In fact, it is the optimal incentive scheme when the consumer surplus associated with local public goods is capitalized into property values.

Thus, the trade-off between equity and efficiency that launches the title of this paper is a trade-off between efficiency in the production of schooling and equity in the allocation of schooling. The trade-off in question is not between allocative equity and allocative efficiency. In fact, recent papers have asserted that very little tension exists between allocative equity and allocative efficiency exists. ${ }^{3}$ The idea is that allocations that are privately efficient but inequitable either inhibit human capital spillovers or exacerbate capital market imperfections. More equitable allocations may be more efficient socially if they are better at producing the positive externalities associated with education or prevent parents' income from playing a determining role in educational attainment. For the purposes of this paper, I simply accept the idea that equitable allocations may also be socially efficient allocations. This is because I

\footnotetext{
${ }^{3}$ See Epple, Romer and Filimon (1984, 1988), Benabou (1993, 1994), Fernandez and Rogerson $(1992,1994)$.
} 
suggest that the following tension is more important. Policies that promote equitable allocation and its ensuing externalities are the same policies that hinder efficient production. A society whose goal is growth must balance these conflicting effects.

To explore this trade-off empirically, I offer evidence on the question of whether U.S. states whose school finance is more centralized--blunting the Tiebout mechanism--have higher schooling costs per pupil. To estimate the effect of school finance centralization on costs, I take advantage of differences between states and differences within a state over time in the state's share of school funding. I find that funding centralization leads to higher per-pupil costs, fewer policies that give incentives for cost-reduction, and lower cost-reducing effort (measured by resistance to unionization and union wage premia). In addition, I show that states whose school finance is more centralized experienced a slower growth in attainment of secondary school education. ${ }^{4}$ This finding indicates that productive inefficiency may be the dominant effect of hindering the Tiebout mechanism or, rephrasing, that the implications of the Tiebout hypothesis for schooling production are at least as important as its implications for schooling consumption.

The remainder of this paper is organized as follows. Section II discusses Tiebout's entrepreneurial model and other models of the local public goods producer. Section III presents this paper's model, which is written--for concreteness--in terms of school districts. I analyze the difference in schools' production efficiency under the alternative regimes of (1) local funding and (2) state-wide, equalized school funding. Section IV shows how we can interpret local, property-tax-based school funding as an application of the theoretical incentive systems suggested

\footnotetext{
4 Before and after the 1940-60 period, it is difficult to calculate a return to secondary schooling by U.S. state. Censuses previous to the 1940 Census did not ask for educational attainment. Among students who attended secondary school from the mid-1960s onwards, relatively few have educational attainment less than high school so that selection bias dominates estimates of the return to education based on income differences between people with less than a high school diploma and people with a high school diploma.
} 
by the model. Section $\mathrm{V}$ comprises empirical evidence on the trade-off between efficiency in production and equity in consumption. The results depend on variation in school fundirg among U.S. states. Section VI concludes.

\section{The Local Public Goods Producer as Entrepreneur}

Tiebout modelled local public goods producers as cost-minimizing entrepreneirs. This section briefly explains why this characterization was the natural outcome of the Tiebout mechanism, the extent to which the characterization is useful, and why it is ultimately wrong. The main purpose is preparation for a more realistic model of the local public goods producer.

\section{A. Tiebout's Entrepreneurial Local Public Goods Producer}

In Tiebout's original paper, the producer of local public goods is envisioned as an entrepreneur and much of the later literature has treated the cost-minimizing, entrepreneurial producer as an assumption. ${ }^{5}$ However, this characterization is not an assumption, but the logical outcome of the Tiebout mechanism of consumer choice combined with the assumption that local public goods are verifiable information. This verifiability assumption was natural owing to the club theory origins of Tiebout's mechanism. Suppose we think about 1 al public goods producers as potential owners of swimming clubs who sell memberships that give access to a swimming pool. The local public good, in this case, is not only observable to members and non-members but its quality is verifiable in the sense that a contract could specifiy hours of operation, the number and training of life-guards, and water conditions.

If the usual Tiebout assumptions (costless mobility, no inter-club externalities, numbers of individuals and potential clubs sufficient to make any club contain identical individuals, lump

\footnotetext{
${ }^{5}$ See Rubinfeld (1987), p 575.
} 
sum membership fees) hold, the potential owners of swimming clubs are driven to minimize average costs. This is berause any owner whose "costs" contained positive rent would be replaced by another who offered marginally less expensive memberships. Also, any owner who acted out of other-than-entrepreneurial motives ("integrationist" motives, for example) would be driven from the market.

\section{B. Why the Entrepreneurial Model and Other Models Fail}

The reason that the entrepreneurial model of the local public goods producer is useful is the recognition that this model is the producer theory generated by the Tiebout mechanism. That is, just as the Tiebout mechanism generates a local public goods consumer tc whom (private goods) consumer theory applies, the Tiebout mechanism generates a local public goods producer to whom (private goods) producer theory applies. The reason that the entrepreneurial model is not realistic--and therefore, of minimal predictive use--is that the verifiability assumption generally does not hold. Most local public goods are observable to consumers but not verifiable. For example, parents may be able to observe the quality of public schools by scrutinizing their children and their neighbors' children. However, the quality of a public school cannot be verified in a court of law $\mathrm{l}$ zause it is not truly encompassed by those items that a contract could specify, such as the student-teacher ratio or required teacher training. ${ }^{6}$

Because verifiability does not hold, the entrepreneurial model fails. This is because the potential seller of the local public good cannot sufficiently specify the good to extract the consumer's valuation of the good. A real estate developer can buy up a jurisdiction, construct sewage and electricity lines, prepare the landscape, and then sell housing lots or already

\footnotetext{
- Police services are another good example. A contract can specify the number and training of police, but cannot fully specify their vigilence or the manner in which they treat citizens.
} 
constructed houses. A potential entrepreneur in local public goods, however, cannot buy up a jurisdiction with overpriced local public goods, improve the public goods production, and then re-sell the houses, extracting a return on his investment. This is entirely due to non-verifiability and it is the reason we do not observe actual entrepreneurs in this field, though we do observe land developers and re-developers of urban real estate. Note that this example implicitly in is a model where the value of local public goods could be capitalized into property prices. This shows that it is the verifiability assumption, rather than assumptions like lump-sum membership fees, that interfere with the entrepreneurial producer. In fact, if local public goods are verifiable, then any "Tiebout-type" set of assumptions that generates allocative efficiency in consumption of the local public goods also generates the cost-minimizing entrepreneurial public goods producer.

The next section builds a more useful model in which local public goods are observable but non-verifiable. Before leaving this section, however, a brief discussion of other models of local goods producer is warranted.

In Niskannen's $(1971,1975)$ classic monopoly model of the public goods producer, the bureaucrat's objective is to maxin:ize the output of the local public good. This is because larrer output is assumed to confer greater salary, prestige, and ability to bestow rents on others. The bureaucrat acts as a monopolist, producing the public good to the point where the financial sponsor of the good has his consumer surplus exhausted. Typically, output is expanded beyond the point of efficient provision. The difficulty with this model, for local public goods production at least, is that it gives no role to a Tiebout mechanism. Even a weak Tiebout mechanism, where consumers only switch jurisdictions when the difference in consumer surplus exceeds a sizable mobility cost, would discipline the monopoly bureaucrat. 
Romer and Rosenthal $(1979,1982 \mathrm{a}, 1982 \mathrm{~b}, 1982 \mathrm{c})$ relax the monopoly bureaucrat model by allowing the bureaucrat to be disciplined by voters. In their models, the bureaucrat is able to use his control of the agenda to expand the level of output beyond that preferred by the median voter. The bureaucrat, by virtue of having more information about public good production than the typical voter, suts the voting agenda and is able to limit the choices of output levels such that the median voter's choice among those available is greater than the median voter's most preferred level. These models clearly contain important insight, but they still have difficulty coping with the Tiebout mechanism. This is because it is not clear why consumers would choose a jurisdiction where bureaucrats set the agenda and consumers chose among a limited set of alternatives with a simple majority vote. In practice, most consumers elect representatives--such as a school board--who have substantially more information about the local public good than the average voter and, therefore, more control of the agenda. Since legislative structure is an aspect of public goods production that can be well specified in a contract, the Tiebout hypothesis predicts that legislative structures that systemically produce lower surplus for consumers will be driven out of the market.

All this is not to deny ti - usefulness of bureaucratic, agenda-setting models. These models explain how the local public goods producer uses and controls the rent allowed by the Tiebout mechanism under which he functions. The model I present in the next section explains how the Tiebout mechanism determines the rent available, but I implicitly assume that the school acts according to the bureaucratic models once the available rent is determined.

Since local public goods producers are typically regulated by a person or group elected by voters ${ }^{7}$ rather than directly regulated by majority vote, the model I present in the next section

\footnotetext{
7 Alternatively, school boards may be appointed by elected officials.
} 
assumes that the producer faces a regulator who represents and is ultimately responsible to voters. For concreteness, note that under the median voter model, this regulator represents the preferences of the median voter in the jurisdiction.

\section{A Theory of the Local Public Goods Producer}

In this section, I present a model of a school board regulating a school district. In addition to Tiebout (1956), the model derives from the theory of incentives for regulation of quality, especially Laffont and Tirole (1993). ${ }^{8}$ The essential insight is that allowing the Tiebout mechanism to function gives the school board an additional instrument so that a higher level of social welfare can be achieved, through a more optimal combination of costs and quality, than is possible under any regime without a Tiebout mechanism. In effect, the Tiebout mechanism gives the board a measure of the demand for the school district--for instance, local property values that capitalize the value of local public schools. If the board does not have a measure of demand, any incentives it creates to keep costs low crowd out incentives to keep quality high (and vice versa). Unlike other models of the local public goods producer, this model acknowledges all of the following: (1) the Tiebout mechanism provides incentives for local goods producers effect on the provision of local public goods, (2) the unverifiability of public goods quality, and (3) the way that local public goods providers are typically regulated by representatives of the residents. In terms of the theory of regulation, the extent to which the Tiebout mechanism is allowed to function effectively changes the informational assumptions under which the problem is solved. ${ }^{9}$

\footnotetext{
8 For transparency, I closely follow Laffont and Tirole's (1993) notation where it is not inconvenient.

9 This application demonstrates the usefulness of the theory of incentives in regulation, especially as the application works generally for local public goods, not only for schooling.
} 


\section{A. The Basic Problem}

A school board facing a school district wishes to achieve two goals, cost minimization and quality maximization. The board is assumed to have imperfect information both about the school district's cost function and its quality provision. The school accurately reports its costs to the board, but the board does not know the parameters of the cost function, so that it cannot determine exactly how much cost-reducing effort the school exerted. Cost-reducing effort is assumed to cause disutility to the school. The school board collects tax revenue and reimburses the school for its costs by a mutually-agreed-upon contract--this contract is to be determined in the model. Residents, from whom taxes are collected, all observe school quality but quality is unverifiable. Providing quality is costly for the school, either in terms of money or effort.

This is the basic problem that I solve under two scenarios. In the first scenario, the board and school district work under a perfect Tiebout mechanism. We can think of this scenario as completely local school finance. The second scenario is state-level school finance or perfect expenditure equalization among local districts. The essential characteristic of the second scenario is that the board must distribute money to schools equally or, at least, only on the basis of reported cost factors (such as the number of students with disabilities). Obviously, these two scenarios represent the extremes between which most school districts fall.

\section{B. Set-Up of the Model}

Some additional assumptions are needed to make the model precise and tractable. I assume that each resident has one school-aged child. In order to abstract from multiple-agent problems, it may be helpful to think of the "school" as a single administrator who has ultimate control over the distribution of the money given by the board. The administrator treats the teachers as part of his costs; by effort on his part, he can achieve the same student results with 
lower costs. Realistic examples of such cost-reducing efforts are more careful selection of teachers, careful choice ant husbanding of school equipment and buildings, and greater monitoring of staff. The schnol's cost function and the residents' demand function are linear-this allows a closed-form solution.

The school's cost. C . is a function of its enrollment, $\mathrm{n}$, its cost-reducing effort, e, its quality, $\mathrm{q}$, and a cost parameter $\beta$. The cost parameter is known to the school (before it signs a contract) but unknown to the board. The linear cost function is:

$$
C=(\beta+q-e) n
$$

where

$$
\beta \in(\boldsymbol{\beta}, \bar{\beta})
$$

Note that a school has "innate" low costs when the cost parameter $\beta$ is low (close to $\beta$ ). Equation (1) has a "scale effect" so that a low cost parameter, high cost-reducing effort, or high quality is more valuable in a school with greater enrollment.

The board gives the school a budget, b. The school's rent is given by:

$$
R=b-C-\psi(e)
$$

where $\psi^{\prime}>0, \psi^{\prime \prime}>0, \psi^{\prime \prime} \cdot 0^{10}$

Residents observe the quality of the school and derive a gross surplus from sending their child to the school. Recalling that we require a linear demand function for simplicity, the gross surplus is:

$$
S^{2}(n, q, \theta)=(A+k q-h \theta) n-\frac{B}{2} n^{2}-\frac{(k q-h \theta)^{2}}{2}
$$

where $\theta$ is a demand parameter such that

10 These assumptions mean that effort is costly and that increasing effort is increasingly costly (convex). The condition $\psi^{\prime \prime \prime} \geq 0$ is sufficient for concavity of the school board's problem. 
and where $\mathrm{A}>0, \mathrm{~B}>0, \mathrm{~h}>0$, and $\mathrm{k}>0$ are known constants. The demand parameter, $\theta$, is known to the school but unknown to the school board. The interpretation of the demand function given by (4) is straightforward. Ignoring quality and the demand parameter, the gross surplus is simply quadratic ,.. enrollment: $A n-(B / 2) n^{2}$. Thus, the gross surplus associated with a school increases in student enrollment but at a decreasing rate. Think of the term $(\mathrm{kq}-\mathrm{h} \theta)$ as a adjustment for a school's higher quality $(q \uparrow)$ and any of its innate characteristics that raise demand for it $(\theta \downarrow)$. (For notational convenience that will become clear, higher $\theta$ means worse innate characteristics.' An improvement in the adjustment term $(\mathrm{kq}-\mathrm{h} \theta)$ increases the gross surplus quadratically and by an amount proportionate to enrollment: $(\mathrm{kq}-\mathrm{h} \theta) \mathrm{n}-(\mathrm{kq}-\mathrm{h} \theta)^{2} / 2$. Thus, when quality or some innate school attribute improves, the surplus associated with each additional student increases but the gross surplus associated with the school in the absence of any students falls.

\section{The Model Under a Short-Run Tiebout Mechanism}

The difference between short-run and long-run Tiebout mechanisms is that short-run mechanisms, such as prop ty value capitalization, do not depend on an elastic supply of nc " jurisdictions, while long-run mechanisms do. I solve the model under short-run Tiebout equilibrium because it is more realistic, but at the end of this section, I deal very briefly with the model under long-run Tiebout equilibrium because it is instructive. For solving the model, the most important property of the short-run is that school districts can vary in their "innate" cost conditions. In the long-run, schools districts with poor innate cost conditions would be driven out of the market, so there would be no variation in innate cost conditions.

Suppose that the market for local public goods is in a short-run Tiebout equilibrium on 
the consumer side. That is, consumers have sorted themselves into residents of school districts such that no resident or group of rosidents could be made better off by switching districts. It is necessarily true then that each resident's marginal utility of sending his child to the school is equal to what he pays for the school. The payment for the school is effectively a lump sum fee or "price," p, in each district siske each district's residents are homogeneous. In the next section, I make this idea concrete using property value capitalization, which is the most plausible mechanism by which the tax-price and marginal utility of schools are equated in the short-run.

The school board, which does not know either $\beta$ or $\theta$, knows that residents equate their marginal utility of the school to the price, p. Therefore, the partial derivative of the gross surplus with respect to the number of residents (equal to enrollment) is equal to $p$ :

$$
\frac{\partial S^{2}}{\partial n}=p=A+k q-h \theta-B n
$$

The school board can solve equation (6) to obtain school quality, q, in terms of the price of the district, $p$, and its enrollment, $n$, which are known.

$$
q=\frac{p-A+h \theta+B n}{k}
$$

Using (7), the board can eliminate school quality from the equations for the residents' gross surplus and the school's cost func ion.

$$
\begin{gathered}
S^{g}(p, n)=\frac{B}{2} n^{2}+p n-\frac{1}{2}(p-A+B n)^{2} \\
C=\left(\beta+\frac{h \theta}{k}-e+\frac{p-A+B n}{k}\right) n
\end{gathered}
$$

We can rewrite (9) to solve for cost-reducing effort, e,

$$
e=\beta+\frac{h \theta}{k}+\frac{p-A+B n}{k}-\frac{C}{n}
$$

and substitute the result into the school's rent equation

$$
R=b-C-\Psi(e)=b-C-\psi\left(\beta+\frac{h \theta}{k}+\frac{p-A+B n}{k}-\frac{C}{n}\right)
$$

Owing to the linear formulation, the unknown parameters $\beta$ and $\theta$ enter equation (11) 
only through the combination

$$
\gamma \equiv \beta+\frac{h \theta}{k}
$$

so we can rewrite equation (11) as

$$
R=b-C-\Psi(e)=b-C-\Psi\left(\gamma+\frac{p-A+B n}{k}-\frac{C}{n}\right)
$$

and think about the distributivis $F($.$) of \gamma .^{11}$

Social welfare, in this case, is simply the residents' gross surplus minus the amount they must pay for the school district plus the school's rent

$$
\begin{aligned}
W & =S^{2}-(1+\lambda) b+R \\
& =\frac{B}{2} n^{2}+p n-\frac{1}{2}(p-A+B n)^{2}-(1+\lambda) b+R \\
& =\frac{B}{2} n^{2}+p n-\frac{1}{2}(p-A+B n)^{2}-(1+\lambda)(R+C+\Psi(e))+R \\
& =\frac{B}{2} n^{2}+p n-\frac{1}{2}(p-A+B n)^{2}-(1+\lambda)\left[\left(\gamma-e+\frac{p-A+B n}{k}\right) n+\psi(e)\right]-\lambda R
\end{aligned}
$$

The board is assumed to maximize expected social welfare, where expectations are taken over the various realizations of $\gamma$. The board is assumed to make a take-it-or-leave-it offer to the school in which, for each value of $\gamma$ that the school announces, the board specifies a budget $\mathrm{b}(\gamma)$, an average cost to realize $\mathrm{C}(\gamma)$, a price for residents $\mathrm{p}(\gamma)$, and an enrollment $\mathrm{n}(\gamma)$. Given that $b, C, p$, and $q$ are all functions of $\gamma$, we can also write $U$ and $e$ as functions of $\gamma$ : $U(\gamma)$ and $e(\gamma)$. Thus, we can write the board's maximization program as:

$$
\max _{p(\gamma),(\gamma),(\gamma), \pi(\gamma)} \int_{I}^{\bar{\gamma}}\left\{\frac{B}{2} n^{2}+p n-\frac{1}{2}(p-A+B n)^{2}-(1+\lambda)\left[\left(\gamma-e+\frac{p-A+B n}{k}\right) n+\psi(e)\right]-\lambda R\right\} d F(\gamma)
$$

subject to:

(16) Incentive Compatability

11 The fact that $\beta$ and $\theta$ enter only as a linear combination is the feature of linearity that allows a closed-form solution. It effectively reduces the problem from a two-dimentional to a one-dimensional adverse selection problem. 


$$
\dot{R}(\gamma)=-\psi^{\prime}(e) \quad \text { where } \dot{R}=\frac{d R}{d \gamma}
$$

(17) Individual Rationality

$$
R(\bar{\gamma}) \geq 0
$$

(18) Second-Order Condition

$$
d-1 \leq 0 \quad \text { where } i=\frac{d e}{d \gamma}
$$

In the Technical Appendix, the constraints shown in equations (16) through (18) are derived and the maximization program is solved. ${ }^{12}$ However, interpretations of the constraints are worth stating here. Equation (16) is the Incentive Compatability constraint. It acknowledges that schools with costs that are innately low (low $\beta$ ) or demand that is innately high (low $\theta$ ) can mimic schools with worse innate attributes. When a better school (low $\gamma \equiv \beta+(\mathrm{h} \theta) / \mathrm{k}) \mathrm{mimics}$ a worse school (high $\gamma$ ), it can achieve the expected levels of enrollment and cost while exerting less cost-reducing effort and/or offering lower quality. The school can achieve a specific decrease in its disutility of effort for every improvement in its innate cost or demand parameters. Therefore, a school board must "bribe" the school to exert effort and offer quality by offering the school with better parameters the same rent it could achieve by mimicking a worse school. This generates the incentive compatability constraint which says that the school's rent must increase as its parameters improve at the same rate that the school's disutility falls as its effort falls. Note that this Incentive Compatability constraint guarantees that the school's reported $\gamma$ will always be truthful.

The interpretation of the Individual Rationality constraint is simpler. The school must be willing to accept the school board's offer so it must earn non-negative rent. This constraint

12 For brevity, the Technical Appendix is currently available from the author, rather than appended to the paper. This material is confined to an appendix because the procedures are not original to this paper. See Laffont and Tirole (1993) for a general discussion of solution methods. 
is only binding for schools that have the worst possible cost and demand parameters $(\bar{\gamma} \equiv \bar{\beta}+(\mathbf{h} \bar{\theta}) / \mathbf{k})$.

The second-order condition given by equation (18) merely requires that cost-reducing effort does not increase so much for a marginal worsening in the innate cost and demand parameters that achieved cost actually falls. Equation (18) could also be written as

$$
\dot{C}(\gamma) \geq 0
$$

The solution is characterized by three equations:

$$
\begin{gathered}
(1+\lambda) p-\lambda B n=(1+\lambda)\left(\gamma-e+\frac{p-\lambda+B n}{k}\right) \\
\text { or } \frac{\partial S^{e}}{\partial n}+\frac{d p n}{d n}=(1+\lambda) \frac{\partial C}{\partial n}
\end{gathered}
$$

$$
\begin{gathered}
(1+\lambda) k n-k(p-\lambda+B n)=(1+\lambda) n \\
\text { or } \frac{\partial S^{g}}{\partial q}+\lambda \frac{\partial p}{\partial q} n=(1+\lambda) \frac{\partial C}{\partial q} \\
\psi^{\prime}(e)=n-\frac{\lambda}{1+\lambda} \frac{F(\gamma)}{f(\gamma)} \Psi^{\prime \prime}(e)
\end{gathered}
$$

Equation (20) shows that the solution equates the marginal social utility of the schoo. 'left side of the equality) and the marginal social cost of the school (right side). Note that the marginal social utility is composed of the marginal utility to residents and the marginal financial gain. Equation (21) shows the solution equates the marginal social utility of school quality (left side) to its marginal social cost (right side). Finally, equation (22) demonstrates that the solution balances the marginal social benefit of inducing higher effort (left side) with its marginal social cost (right side). We can see this interpretation if we consider raising the effort of each of the $\mathrm{f}(\gamma) \mathrm{d} \gamma$ schools that have $\gamma \in\left[\gamma^{*}, \gamma^{*}+\mathrm{d} \gamma\right]$ by $\delta$. Costs decrease by $\left[\mathrm{n}-\psi^{\prime}\left(\mathrm{e}\left(\gamma^{*}\right)\right)\right] \delta \mathrm{e}$ for these 
schools, yielding a social benefit of $(1+\lambda)\left[n-\psi^{\prime}\left(e\left(\gamma^{*}\right)\right)\right](\delta \mathrm{e}) f\left(\gamma^{*}\right) \mathrm{d} \gamma$. However, we can only induce the greater effort by allowing each of the $F\left(\gamma^{*}\right)$ schools that have $\gamma \in\left[\chi, \gamma^{*}\right]$ to increase, its rent by $\psi^{\prime \prime}\left(\mathrm{e}\left(\gamma^{*}\right)\right)(\delta \mathrm{e})(\mathrm{d} \gamma)$. The social cost of the extra rents is $\lambda \psi^{\prime \prime}\left(\mathrm{e}\left(\gamma^{*}\right)\right)(\delta \mathrm{e})(\mathrm{d} \gamma) \mathrm{F}\left(\gamma^{*}\right)$. When we equate the social henefit and social cost of inducing extra effort, we get equation (22).

For our purposes, s.: important feature of the solution given by equations (20) through (22) is that the desire for miality does not affect cost reduction. The equations that guarantre optimal cost-reducting effort and that guarantee optimal quality are separable. The combination of price and enrollment targets is used to set quality. The combination of the budget and cost target is used to set cest reduction. Equation (22), which specifies the optimal choice of costreducing effort, does not contain the parameter $k$, which measures how much utility increases in school quality. Thus, for any optimal level of cost-reducing effort, $\hat{\mathbf{e}}$, set by equation (22), equations (20) and (21) choose a combination of price, p, and enrollment, $n$, to guarantee optimal quality.

Laffont and Tirole show that the solution given by equations (20) through (22) can be implemented by a menu of contracts that the school board offers to the school. If the school accepts the menu, it get $t \cdot$ contract that corresponds to the innate conditions it annouces, $\therefore$ Each contract specifies that the school's budget is reduced linearly in its realized costs and increased linearly in a quality index that is equal to its realized enrollment corrected by its price:

$$
\begin{gathered}
b=\alpha_{0}-\alpha_{1} c+\alpha_{2} \frac{p+B n}{k} \\
\text { where } \alpha_{1}(\gamma)=\frac{\psi^{\prime}(\varepsilon(\gamma))}{\hat{h}(\gamma)}-1 \text { and } \alpha_{2}(\gamma)=\hat{\hbar}(\gamma) \alpha_{1}(\gamma)
\end{gathered}
$$

Note that $\hat{e}$ and $\hat{n}$ denote the solutions to the school board's optimization program. Equation (23) indicates that the board shares linearly in cost overruns according to the coefficient $\alpha_{1}(\gamma)$. 
The board also shares linearly in overruns of a quality index (equal to enrollment corrected by the school's price) according to the coefficient $\alpha_{2}(\gamma)$. Effectively the board uses two instruments, a cost index and a quality index, to attain its two goals of cost-reducing effort and school quality.

In summary, the model demonstrates that local school finance generates a measur , $f$ demand that can be used, in addition to reported cost, as an instrument to create incentives. Because local finance generates two instruments, cost-reducing incentives do not crowd out quality--that is, create perverse quality incentives.

\section{The Model Under a Long-Run Tiebout Mechanism}

In the classic formulation of the long-run Tiebout hypothesis, there is a infinitely elastic supply of potential school districts. Under these conditions, a school that had bad innate cost conditions (high $\beta$ ) would always be replaced that one with better conditions that could take over the first school's contract and earn a larger rent. In fact, only schools with the minimum $\beta=\beta$ would exist. In this situation, the board would not be faced with the problem of giving incentives for cost reduction since it would know the school's costs and set target costs appropriately. ${ }^{13}$

By design, there could be no crowding out of cost incentives in this scenario. Yet, unverifiable quality and incomplete information about demand parameters mean that the board would still have to give incentives for quality provision through price and enrollment targets. A Tiebout equilibrium would be still be needed so that price and enrollment information could

${ }^{13}$ nder effectively complete information about costs, the solution would be given by equations (20), (21), and a modified equation (22):

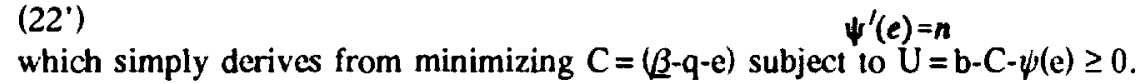


be used to generate information about quality. The implication of this extreme example is that complete cost information would not reduce the need for a Tiebout mechanism to solve the quality problem.

Short-run Tiebout mechanisms, which do not guarantee complete cost information, fit reality so much better that cust implications are the single most powerful test of the Tiebout hypothesis for producers. That is, schools in environments that more closely replicate the assumptions needed to generate a short-run Tiebout mechanism are predicted to have lower costs, all else equal.

E. The Model under State-Level School Finance

In this section, I solve the model supposing that school finance is centralized at the state level, either by an explicit state-wide district, such as exists in Hawaii, or by an absolute expenditure equalization plan. I assume that state school finance achieves allocative equity, which may be but need not be defined as equal per-pupil spending.

That is, it is not necessary to assume that the state sets a level of per-pupil spending and strictly gives each district a budget equal to the spending level times the number of students enrolled. It is sufficient that state-level school finance allocates revenue among all the districts in a state on the basis of any verifiable characteristics except for measures of excess demand for the district. The state can allocate revenue on the basis of enrollment, known student characteristics like disabilities and parents' education, or known school district characteristics like teachers' degrees or the average student's travel distance. However, in order to meaningfully distinguish between state-level and local school finance, the state's allocative rule cannot merely duplicate the Tiebout mechanism by rewarding schools on a measure of excess demand like the residual of property values that cannot be explained by property size or 
attributes. In any case, state-level school finance that approximated local finance would not achieve allocative equity.

Under state-level school finance, incentives for cost-reduction necessarily crowd-out school quality. The logic is as follows. In order to induce cost-reducing effort, the state-level school board must allow the school to keep some rent associated with lower innate costs or higher innate demand. The board must offer a contract in which a school that reports lower costs keeps some of the cost savings. Schools now have the incentive to lower costs by decreasing school quality. This decreased school quality will result in lower demand for the school, but state-level finance makes the school's budget independent of demand. In fact, even the milaest incentive to reduce cost (schools keep a tiny share of cost savings) will give schools the incentive to set school quality at zero. Note that quality equal to zero is not literally a school without a building or teachers, but is a school in which no effort is expended to guarantee that school inputs are purchased efficiently, examined for quality, or used efficiently. Nevertheless, there is a "knife-edge" in this result. The state can guarantee a number of verifiable characteristics through explicit rewards and penalties, but the board cannot induce any (unverifiable) cost-reducing effort without totally eliminating (unverif able) quality.

With the linear model, it is simple to show this formally. ${ }^{14}$ This is because we can redefine the school's innate cost conditions as:

$$
\tilde{\beta}=\beta+q \text { where } \tilde{\beta} \in[\beta+q, \bar{\beta}+q]
$$

This re-definition makes it clear that adding quality has exactly the same effect as increasing the school's innate cost conditions.

14 The crowding-out result does not depend on linearity. Laffont and Tirole give general conditions under which incentives for multiple goals, such as cost-reduction and quality provision, cannot be dichotomized. 
Under state-level school finance, the school board's problem is:

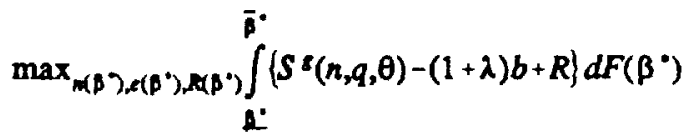

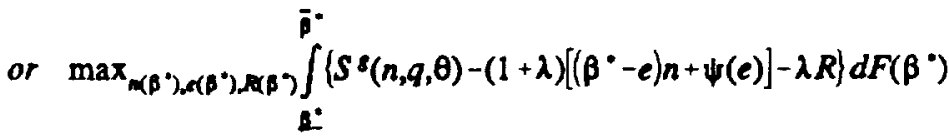

subject to:

(26) Incentive Compatability

$$
\dot{R}\left(\beta^{\circ}\right)=-\psi^{\prime}(e) \quad \text { where } \dot{R}=\frac{d R}{d \beta^{*}}
$$

(27) Individual Rationality

$$
R\left(\overline{\boldsymbol{\beta}}^{*}\right) \geq 0
$$

(28) Second-Order Condition

$$
e-1 \leq 0 \quad \text { where } i=\frac{d e}{d \beta^{*}}
$$

Comparing these equations to the problem given by equations (15) through (18), we see that the board's problem under state-level finance is just a simpler version of its problem under local finance. The board cannot now maximize over price since residents' gross surplus cannot now be written in terms of price, owing to the fact that state-level finance has no means of guaranteeing equality between marginal surplus and price.

The solution to the state-level school board's problem is:

$$
\psi\left(e\left(\beta^{\circ}\right)\right)=q-\frac{\lambda}{1+\lambda} \frac{F\left(\beta^{\circ}\right)}{f\left(\beta^{\circ}\right)} \psi^{\prime \prime}\left(e\left(\beta^{\circ}\right)\right)
$$

Therefore, the school's rent

$$
\begin{gathered}
R=b-C-\Psi\left(e\left(\beta^{*}\right)\right)=b-C-n+\frac{\lambda}{1+\lambda} \frac{F\left(\beta^{*}\right)}{f\left(\beta^{*}\right)} \Psi^{\prime \prime}\left(e\left(\beta^{*}\right)\right) \\
\text { or } R=b-C-n+\frac{\lambda}{1+\lambda} \frac{F(\beta+q)}{f(\beta+q)} \psi^{\prime \prime}(e(\beta+q))
\end{gathered}
$$

is decreasing in q. A rent-maximizing school sets quality at zero. Under state-level 
finance, the school board should choose between a fixed-per-pupil-budget rule which induces maximum cost-reduction bu $\mathrm{u}^{+}$no quality and a cost-plus rule which induces quality but no costreducing effort. Which of these two rules is optimal depends on whether the social welfare is higher when at the minimum cost/minimum quality point or the maximum quality/maximum cost point. An example of a fixid-per-pupil-budget rule would be allocation on a per-pupil basis with adjustments only for immurable pupil characteristics, such as disabilities, and immutable school district characteristics, such as land area. An example of a cost-plus rule would be an allocation on a school input basis with adjustments for teachers' degrees, teachers' experience, teachers' salaries, enrollment in advanced classes, and so on. In reality, most states with anv substantial level of state-level school funding have at least some cost-plus provisions, if by no other means than periodic changing of the adjustments for immutable characteristics (which can be used to reimburse school inputs).

\section{F. Summary of the Model's Predictions}

In summary, the model predicts lower costs for any given level of school quality in states where a greater share of school funding is determined locally and conditions correspond more closely to those needed $f_{i}$ a Tiebout mechanism. The greater the share of school funding determined at the state level, the higher should be per-pupil costs and the lower the social return to schooling, all else--including externalities associated with schooling--equal. The observed relationship between the social return to schooling and the state's share of schooling funding will reflect the balance between lower productive efficiency as the state's share rises and greater positive externalities potentially produced by greater allocative equity as the state's share rises. 


\section{Practical Implementation:}

\section{How Information Generated by the Tiebout Mechanism is Actually}

\section{Used to Give Quality and Cost Incentives to Schools}

In this section, I discuss how local property tax finance with capitalization is an implementation of the optimal contract under the Tiebout mechanism. This applicaw n demonstrates the predictive power of the model in helping us analyze policy choices like that between local-property-tax-based finance and school spending equalization.

Recall that the optimal contract specifies that the school's budget is reduced linearly in a realized cost index and increased linearly in a price-adjusted quality index. The latter part of this contract is actually implemented when a school's budget is equal to a tax rate times the value of property in the school district and property values capitalize the consumer surplus generated by the school (for the marginal resident). The capitalization hypothesis says that, if one school generates greater consumer surplus than other schools, perhaps because of good innate conditions or scarce administrative talent, then the market price of property in the school district is bid up until the new price of the school (equal to the new property value times the tax rate) has risen to eliminate any ex ess consumer surplus. The part of the property price wl. $: h$ is the capitalized value of local schools is the ideal price-adjusted quality index since it perfectly reflects demand for the school at the current price.

School boards also have practical means of making schools absorb some share of overruns in realized costs. This is done by having a two-tiered system of cost reimbursement. Typically, the school board wholly reimburses the school's costs as long as they fall within a fixed budget. If the costs fall outside of this budget, a referendum is usually required to approve additional cost reimbursement. Such referenda cause the administrator responsible for the cost 
overrun to lose considerable reputation and career prospects. To maximize his lifetime utility, the administrator will absorb a ertain percentage of cost overruns before he requests a referendum.

Thus, the type of local school finance we observe approximates the optimal contract dictated by the Tiebout mechanisn, exactly as well as the Tiebout mechanism itself functions.

\section{Empirical Evidence on the Trade-off}

\section{Between Productive Efficiency and Allocative Equity}

The model predicts that as school funding shifts from local to state support, schools will have higher costs for any given level of quality. These higher costs for given quality will, in general, translate into lower growth in educational attainment. The allocative equity model with externalities does not have strong cost predictions but does predict greater growth in educational attainment. In this section, in order to evalate the production efficiency-allocative equity tradeoff, I examine the relationships between the state's share of school funding and cost-reducing incentives in schools, school costs, and the growth of educational attainment.

Evidence that increasing the state's share raises both school costs and educational attainment will be interpreted as support for a balanced trade-off between productive inefficiency and allocative equity. Evidence that increasing the state's share raises educational attainment without proportionate increases in school costs will be interpreted as support for a trade-off that favors allocative equity. Finally, evidence that increasing the state's share raises school costs without proportionate increases in educational attainment will be interpreted as support for a trade-off that favors productive inefficiency.

The empirical strategy is to use changes within U.S. states between 1940 and 1980 in the 
share of public school funding provided by the state. Because individual states have somewhat idiosyncratic school funding systems, cross-section estimates that exploit only the variation across U.S. states at a point in time are likely to confound the effect of state-level funding with numerous unobserved state characteristics. I use within-state changes across ten-year intervals to eliminate much of this concern. This approach is meant to provide suggestive rather than definitive evidence; it has the advantage of providing a comprehensive view of the effect of state-level funding.

The disadvantage of the approach is that is still possible that changes in states' share of funding are correlated with changes in unobserved, state-level determinants of school costs and educational attainment. Such correlation would bias the results toward finding a balanced tradeoff between productive inefficiency and allocative equity. This is because most changes in unobserved determinants would have correlations with school costs that were of the same signs as their correlations with educational attainment. For example, suppose that we do not entirely observe the change in household income in a state. Both changes in school costs and changes in educational attainment are likely to be positively correlated with changes in unobserved household income. Therefore, we would be likely to find not higher school costs for given educational attainment nor greater educational attainment for given school costs, but higher school costs combined with greater educational attainment. ${ }^{15}$

Data are discussed in the Data Appendix and sources are listed under every table. In addition, Appendix Tables 1 and 2 contain descriptive statistics for all the variables.

\section{A. The State's Share of School Funding and Explicit Cost-Reducing Incentives}

15 An alternative approach to solving the problem of potential correlation between observed school funding practices and unobserved determinants of school outcomes is illustrated by Hoxby $(1994 a, b)$. These papers exploit exogenous variation across areas in the degree to which the Tiebout mechanism functions. 
The model predicts that as the state assumes a greater role in school funding, any given cost-reducing incentive such as a "fixed-price" contract will crowd out school quality to an increasing degree. This is because incentives for quality, such as school budgets based on capitalized property values, weaken as the Tiebout mechanism determines less of the variation in the school's budget. Therefore, we expect to see more "cost-plus" provisions (or fewer fixed prices) in state funding as a state assumes a greater percentage of school funding. Table 1 shows, for 1970 and 1980 , each state's share of public school funding and whether each state has significant cost-plus provisions. In practice, virtually all of the cost-plus provisions are increases in state aid for additional teacher experience or teacher degrees, holding constant enrollment, the characteristics of the pupils, and other school district characteristics. To quality as significant, a cost-plus provision must be a component of a type of state aid that forms at least 20 percent of total state aid. Table 1 demonstrates that states with higher shares of school funding are more likely to have cost-plus provisions. The five states with the highest shares in 1980 all had cost-plus provisions (Delaware, Hawaii, Kentucky, New Mexico, and Washington). Only one of the eleven states with the lowest state shares in 1980 had a cost-plus provision (Nebraska was the exception; the ot'.ers were Connecticut, Illinois, Michigan, New Hampshire, New Jersey, Oregon, South Dakota, Vermont, Wisconsin, and Wyoming).

\section{B. The State's Share of School Funding and Per-Pupil Costs}

In the remaining tables, I estimate separate equations for changes from 1940 to 1950 , from 1950 to 1960 , from 1960 to 1970 , and from 1970 to 1980 . The earlier pirriods are useful because more of the variation in educational attainment was driven by secondary school completion in the 1940 s and 1950 s than in the 1960 s and 1970s. Since we are particularly concerned with the implications of state-level funding for growth in educational attainment, 
looking at earlier data is essential.

Table 2 shows weighted least squares estimates ${ }^{16}$ of the effect of a change in the state's share of school funding on the percentage change in per-pupil funding. The four columns correspond to equations for each of the four periods listed above. Apart from the change in the state's share of school spunding, the equation has controls for the change in median earnings, the change in urbanicity, and the change in the number of school districts in the state. Of course, many state characteristics that are relatively fixed, such as region, are eliminated by the first-differences strategy. ${ }^{17}$

Table 2 demonstrates that an increase in the state's share of school funting raised perpupil costs, at least in the earlier periods. For instance, a 10 percentage point increase in the state's share of school spending raised per-pupil spending by 11.1 percent in the $1940 \mathrm{~s}$. The same 10 percentage point increase raised per-pupil spending by 5.6 percent in the $1950 \mathrm{~s}$. The coefficient estimates for the 1960s and 1970s are of the same sign, but are insignificantly different from zero.

Table 3 presents another measure of school costs, the student-teacher ratio. As the student-teacher ratio falls, zacher intensity rises and schooling becomes more costly. In Table 3, we see that an increase in the state's share of school funding lowers the student-teacher ratio. For instance, a 10 percentage point increase in the state's share of funding caused the studentteacher ratio to fall by 0.8 students in the 1940 s and by 0.3 students in the 1970 s.

16 Weighted least squares is necessary because some variables are state averages computed over different numbers of observations. In practice, the estimates were not affected by the absence of weights, weighting by the number of school districts, or weighting by the state populations. The estimates shown are those that weight by the number of school districts.

17 Because there are only 49 state observations (data are not available for Alaska on consistent bases over entire period), the number of covariates must be small. 
In Table 4, I show another measure of school costs, average teacher salary, and two measures of teachers' uniorization. Teachers' unionization and the union wage gap are included because they potentially shcw the resistance of schools to higher costs. That is, a school under strong incentives for cost-reducing effort may be more likely to resist collective bargaining and to resist paying a union pıe'ıium. Table 4 confirms that greater state-level funding raises sciın)l costs and apparently lower resistance to teachers' unions. A 10 percentage point increase in the state's share of school spending raises the average teacher salary by 2.5 percent, raises the percentage of teacher under collective bargaining by 14 percentage points, and raises the union wage premium by 3.5 percentage points.

In summary, Tables 1 through 4 demonstrate that increases in states' shares of school funding have been associated with significant increases in the per-pupil schooling costs. Also, "cost-plus" provisions in state-aid formulae and concessions to teachers' unions provide evidence that increases in states' shares of school funding appear to reduce incentives for cost-reduction.

\section{The State's Share of School Funding and Growth in Educational Attainment}

In this sub-section, I examine changes in the percentage of the population who complete four years of high school. The analysis thus focuses on improvements in educational attainn , At $^{-1}$ that are most attributable to changes in elementary and secondary education. Given the fact that the previous tables showed higher school costs associated with larger state shares, high school completion must rise significantly in the state's share of funding to support the hypothesis of a balanced trade-off or the hypothesis of a trade-off favoring allocative equity.

The dependent variabie in Table 5 in the change in the percentage of males who 
completed high school over each period. ${ }^{18}$ Table 5 shows that a higher state share of school funding not only does not appear to improve educational attainment, but worsens it by a small but statistically significant amount. A ten percentage point increase in the state's share of school funding generated a 0.4 percentage point decrease in high school completion in the 1950 s and generated a 1.0 percentage poin decrease in high school completion in the $1970 \mathrm{~s}$. The coefficient estimates for the other two periods have the same sign but are insignificantly different from zero.

This evidence corresponds with that of Peltzman (1995) who finds that an increased state share of school funding is associated with lower growth in test scores in the state. For 1970 through 1990, he examines both college entrance examination scores (SAT and ACT) and Armed Forces Qualifications Test (AFQT) scores.

Combined with the evidence of the previous sub-section, this section's results support the hypothesis that lost growth in educational attainment due to productive inefficiency outweighs improved growth due to allocative equity. Not only does educational attainment not rise proportionately with school costs as the state's share rises, it actually falls or--at best--stays constant. That is, I have show . not just that educational attainment conditional on school spending falls, but that unconditioned educational attainment falls.

\section{Conclusions}

The results of the previous section do not show that spending equalization can never be justified. Rather, they show that state-level spending needs to be justified on pure equity

\footnotetext{
18 Note that this variable is defined so as to get the educational attainment of people who attended school in the relevant period. That is, the people whose educational attainment is examined (when they are aged 25 to 29) are those people who were aged 5 to 9 at the beginning of the relevant period. Their educational attainment is compared to that of people in the same state who were aged 5 to 9 at the beginning of the previous period.
} 
grounds because, in practice, positive production externalities generated by allocative equity are dominated by production inefficiencies due to the loss of incentives as the Tiebout mechanism determines smaller shares of school budgets.

The principal goal of this paper was to provide a realistic model of how the Tiebout mechanism determines the conduct of local public goods producers. The model provided depends on an insight that the Tiebout mechanism generates information that can be used to give better incentives to local public goods producers. I demonstrate that school funding based on local property taxes (with capitalization) is a real-world example of a regulatory scheme that efficiently uses demand information generated by the Tiebout mechanism. This model provides plausible underpinnings for empirical evidence that stronger competition among local jurisdictions lowers the cost of any given quality of local public goods. 


\section{Bibliography}

Benabou, Roland. (1993) "Workings of a City: Location, Education, and Production." The Quarterly Journal of Economics, August 1993, 619-52.

---. (1994) "Human Capital, Inequality and Growth: A Local Perspective" European Economic Review, 38, 3/4, 817-26.

Borland, Melvin V. and Roy M. Howsen. (1992) "Student Academic Achievement and the Degree of Market Concentration in Education." Economics of Education Review, Vol. II, No. 1, 31-39.

Eberts, Randall W. and T.J. Gronberg. (1981) "Jurisdictional Homogeneity and the Tiebout Hypothesis." Journal of Urban Economics, 10, 227-39.

-..-, E.K. Schwartz, and Joe A. Stone. (1990) "School Reform, School Size, and Student Acrievement." Economic Review Federal Reserve Bank of Cleveland, 26.2, 2.

Epple, Dennis and Richard Romano. (1993) "Competition between Private and Public Schools, Vouchers, and Peer Group Effects." Carnegie Mellon University mimeo.

Epple, Dennis, R. Filimon, and T. Romer. (1984) "Equilibrium among Local Jurisdictions: Toward an Integrated Treatment of Voting and Residential Choice" Journal of Public Economics, 17,281-308.

----. (1983) "Housing, Voting, and Moving: Equilibrium in a Model of Local Public Goods with Multiple Jurisdictions" in J. Henderson, ed. Research in Urban Economics, 3, 5990.

Epple, Dennis and A. Zelnitz. (1981) "The Implications of Competition among Jurisdictions: Does Tiebout Need Politics?" Journal of Political Economy, 89, 1197-1217.

Fernandez, Raquel and Richard Rogerson. (1995) "On the Political Economy of Education Subsidies" Review of Economic Studies, 62, 2, 249-62.

----. (1995) "Public Education and Income Distribution: A Quantitative Evaluation of Finance Reform" mimeo.

Hoxby, Caroline M. (1994a) "Does Competition Among Public Schools Benefit Students and Taxpayers? Evidence from Natural Variation in School Districting." NBER Working Paper No. 4979.

----. (1994b) "Do Private Schools Provide Competition for Public Schools?" NBER Working Paper No. 4978.

Inman, Robert P. (1987) "The 'New' Political Economy" Chapter 12 in Alan J. Auerbach and 
Martin Feldstein, eds. Handbook of Public Economics. Amsterdam: North-Holland.

Laffont, Jean-Jacques and Jean Tirole. (1993) A Theory of Incentives in Procurem 'nt and Regulation. Cambridge, Massachusetts: The MIT Press.

Niskanen, W. (1971) Bureaucracy and Representative Government. Chicago: Aldine-Atherton Press.

---. (1975) "Bureaucrats and Politicians" Journal of Law and Economics, 18, 617-4 ;.

Peltzman, Sam. (1995) "Political Economy of Public Education: Non-Colleg " Bound Students." University of Chicago, Center for the Study of the Economy and the State Working Paper No. 108.

--. (1992) "The Political Economy of the Decline of American Public Education." University of Chicago, Center for the Study of the Economy and the State Working Paper No. 78.

Romer, T. and H. Rosenthal. (1978) "Political Resource Allocation, Controlled Agendas, and the Status Quo" Public Choice, 33, 27-43.

Rubinfeld, Daniel L. (1987) "The Economics of the Local Public Sector" Chapter 11 in Alan J. Auerbach and Martin Feldstein, eds. Handbook of Public Economics. Amsterdam: North-Holland.

Tiebout, Charles. (1956) "A Pure Theory of Local Public Expenditures." Journal of Political Economy, 64, 416-24. 
Table 1

Percentage of Public School Spending Accounted for by State and "Cost-Plus" Provisions in State Funding for Public Schools

\begin{tabular}{|c|c|c|c|c|}
\hline \multirow[b]{2}{*}{ State } & \multicolumn{2}{|c|}{1970} & \multicolumn{2}{|c|}{1980} \\
\hline & $\begin{array}{l}\text { Percentage of Public } \\
\text { School Spending } \\
\text { Accoun id for by } \\
\text { : }:\end{array}$ & $\begin{array}{c}\mathrm{CP}=\text { Significant } \\
\text { Cost-Plus Prnvision, } \\
\mathrm{cp}=\text { Minor Cost }- \text { Plus } \\
\text { Provision }\end{array}$ & $\begin{array}{l}\text { Percentage of Public } \\
\text { School Spending } \\
\text { Accounted for by } \\
\text { State }\end{array}$ & $\begin{array}{c}C P=\text { Significant } \\
\text { Cost-Plus Provision, } \\
\text { cp = Minor Cost- } \\
\text { Plus Provision }\end{array}$ \\
\hline Alabama & 70 & $\mathrm{CP}$ & 64 & $\mathrm{CP}$ \\
\hline Arizona & 2 & & 53 & $\mathrm{CP}$ \\
\hline Arkansas & 60 & $\mathrm{CP}$ & 49 & $\mathrm{CP}$ \\
\hline California & 43 & & 65 & \\
\hline Colorado & 37 & & 39 & \\
\hline Connecicut & 27 & & 28 & \\
\hline Delaware & 88 & $\mathrm{CP}$ & 66 & $\mathrm{CP}$ \\
\hline Florida & 74 & $\mathrm{CP}$ & 54 & \\
\hline Georgia & 66 & $\mathrm{CP}$ & 55 & $\mathrm{CP}$ \\
\hline Hawaii & 75 & $\mathrm{CP}$ & 77 & $\mathrm{CP}$ \\
\hline Idaho & 54 & & 57 & \\
\hline Illinois & 47 & & 33 & \\
\hline Indiana & 39 & $\mathrm{CP}$ & 53 & $\mathrm{CP}$ \\
\hline Iowa & 45 & & 38 & \\
\hline Kansas & 35 & & 41 & \\
\hline Kentucky & 68 & $\mathrm{CP}$ & 65 & $\mathrm{CP}$ \\
\hline Louisiana & 70 & $\mathrm{CP}$ & 53 & $\mathrm{CP}$ \\
\hline Maine & 62 & & 47 & \\
\hline Maryland & 33 & & 35 & \\
\hline Massachusetts & 19 & & 34 & \\
\hline Michigan & 45 & & 29 & \\
\hline Minnesota & 61 & & 54 & $\mathrm{CP}$ \\
\hline Mississippi & 78 & $\mathrm{CP}$ & 58 & $\mathrm{CP}$ \\
\hline Missouri & 48 & & 37 & \\
\hline Montana & 38 & & 46 & \\
\hline
\end{tabular}

This table is continued on the next page. A significant cost-plus provision must be a component of the formula for a type of state aid that absorbs at least 25 percent of the state school aid budget. Qualifying cost-plus provisions are all adjustments in state aid for teacher experience and degrees, except for the provision indicated by "cp."

sources: Public School Finance Programs, 1972 and 1982 Censuses of Governments. 
Table 1 Continued

Percentage of Public School Spending Accounted for by State and "C ost-Plus" Provisions in State Funding for Public Schools

\begin{tabular}{|c|c|c|c|c|}
\hline \multirow[b]{2}{*}{ State } & \multicolumn{2}{|c|}{1970} & \multicolumn{2}{|c|}{1980} \\
\hline & $\begin{array}{l}\text { Percentage of Public } \\
\text { School Spending } \\
\text { Accounted for by } \\
\text { State }\end{array}$ & $\begin{array}{c}C P=\text { Significant } \\
\text { Cost-Plus Provision, } \\
\mathrm{cP}=\mathrm{M} \text { inor Cost-Plus } \\
\text { Provision }\end{array}$ & $\begin{array}{l}\text { Percentage of Public } \\
\text { School Spending } \\
\text { Accounted for by } \\
\text { State }\end{array}$ & $\begin{array}{c}C P=\text { Significant } \\
\text { Cost-Plus Provision, } \\
\mathrm{CP}=\mathrm{M} \text { inor Cost-Plus } \\
\text { Provision }\end{array}$ \\
\hline N ebraska & 23 & $C P$ & 18 & $C P$ \\
\hline N evada & 68 & & 37 & \\
\hline New Hampshire & 11 & & 9 & \\
\hline New Jersey & 24 & & 33 & \\
\hline New M exico & 74 & & 68 & $C P$ \\
\hline New Y ork & 54 & & 40 & \\
\hline N orth Carolina & 57 & $C P$ & 63 & $C P$ \\
\hline North Dakota & 42 & & 42 & \\
\hline Ohio & 32 & $C P$ & 38 & $C P$ \\
\hline Oklahoma & 55 & & 49 & \\
\hline Oregon & 32 & & 32 & \\
\hline Pennsylvania & 56 & & 42 & \\
\hline R hode Island & 59 & & 36 & \\
\hline South Carolina & 66 & $C P$ & 48 & $C P$ \\
\hline South Dakota & 25 & & 26 & \\
\hline Tennessee & 63 & $C P$ & 39 & $C P$ \\
\hline Texas & 57 & $C P$ & 44 & $C P$ \\
\hline Utah & 68 & & 48 & $C P$ \\
\hline V ermont & 42 & & 26 & \\
\hline Virginia & 33 & & 38 & \\
\hline W ashington & 57 & $\mathrm{CP}$ & 72 & $\mathrm{cp}$ \\
\hline W est V irginia & 69 & $C P$ & 56 & $C P$ \\
\hline Wisconsin & 37 & & 32 & \\
\hline Wyoming & 44 & & 31 & \\
\hline
\end{tabular}

A significant cost-plus provision must be a component of the formula for a type of state aid that absorbs at least 25 percent of the state school aid budget. Qualifying cost-plus provisions are all adjustments in state aid for teacher experience and degrees, except for the provision indicated by "cp."

sources: Public School Finance Programs, 1972 and 1982 Censuses of Governments. 
Table 2

Effect on Per-Pupil Spending of Change in State's Share of School Expenditure and Other Variables

\begin{tabular}{|c|c|c|c|c|}
\hline & \multicolumn{4}{|c|}{ Dependent Variable: Percentage Change in Per-Pupil Spending } \\
\hline & $\begin{array}{l}1950-40 \\
\text { Changes }\end{array}$ & $\begin{array}{l}1960-50 \\
\text { Changes }\end{array}$ & $\begin{array}{l}1970-60 \\
\text { Changes }\end{array}$ & $\begin{array}{l}1980-70 \\
\text { Changes }\end{array}$ \\
\hline $\begin{array}{l}\text { Change in Percentage of } \\
\text { Public School Spending } \\
\text { Arcounted for by State }\end{array}$ & $\begin{array}{l}1.11 *^{*} \\
(.31)\end{array}$ & $\begin{array}{l}0.56^{\circ} \\
(0.36)\end{array}$ & $\begin{array}{c}0.22 \\
(0.30)\end{array}$ & $\begin{array}{c}0.20 \\
(0.14)\end{array}$ \\
\hline $\begin{array}{l}\text { Change in Median } \\
\text { Eamings of Males Aged } \\
25+\end{array}$ & $\begin{array}{l}1.02^{-} \\
(0.19)\end{array}$ & $\begin{array}{l}0.83^{*} \\
(0.25)\end{array}$ & $\begin{array}{l}0.64^{*} \\
(0.13)\end{array}$ & $\begin{array}{l}0.81^{\circ} \\
(0.28)\end{array}$ \\
\hline $\begin{array}{l}\text { Change in Percentage of } \\
\text { Population who are } \\
\text { Urban }\end{array}$ & $\begin{array}{c}0.01 \\
(0.80)\end{array}$ & $\begin{array}{l}-0.61 \\
(0.37)\end{array}$ & $\begin{array}{l}-1.98^{*} \\
(0.79)\end{array}$ & $\begin{array}{c}0.11 \\
(0.13)\end{array}$ \\
\hline $\begin{array}{l}\text { Change in Number of } \\
\text { School Districts Per } \\
\text { Square Mile }\end{array}$ & $\begin{array}{c}0.09 \\
(0.06)\end{array}$ & $\begin{array}{l}-0.35 \\
(0.21)\end{array}$ & $\begin{array}{l}-0.53^{-} \\
(0.14)\end{array}$ & $\begin{array}{l}-0.10 \\
(0.48)\end{array}$ \\
\hline Constant & $\begin{array}{l}-32.97^{*} \\
(14.14)\end{array}$ & $\begin{array}{l}129.77^{\circ} \\
(40.12)\end{array}$ & $\begin{array}{c}38.07^{*} \\
(9.62)\end{array}$ & $\begin{array}{l}29.27^{*} \\
(11.53)\end{array}$ \\
\hline No. of Observations & 49 & 49 & 49 & 49 \\
\hline R-Squared & 0.60 & 0.29 & 0.51 & 0.31 \\
\hline
\end{tabular}

standard errors in parentheses; " indicates that coefficient is significantly different from zero at the 0.05 level of significance; " indicates that coefficient is significantly different from zero at the 0.01 level of significance.

Notes: observations are all U.S. states except Alaska (District of Columbia not included); weighted least squares estimates; all dollar amounts in $\$ 1990$.

sources: $1938-40,1948-50$, and 1958-60 Biennial Surveys of Education; 1972 and 1982 Censuses of Government; 1940 and 1950 Public Use Microdata Samples of the Census of Population; 1960, 1970, and 1980 summary tables of the Census of Population. 
Table 3

Effect on Student-Teacher Ratio of Change in State's Share of School Expenditure and Other Variables

\begin{tabular}{|c|c|c|c|c|}
\hline & \multicolumn{4}{|c|}{ Dependent Variable: Change in Student-Teacher Ratio } \\
\hline & $\begin{array}{l}1950-40 \\
\text { Changes }\end{array}$ & $\begin{array}{l}1960-50 \\
\text { Changes }\end{array}$ & $\begin{array}{l}1970-60 \\
\text { Changes }\end{array}$ & $\begin{array}{l}1980-70 \\
\text { Changes }\end{array}$ \\
\hline $\begin{array}{l}\text { Change in Percentage of } \\
\text { Fublic School Spendistg } \\
\text { Accounted for by State }\end{array}$ & $\begin{array}{l}-0.08^{\circ} \\
(0.03)\end{array}$ & $\begin{array}{l}-0.07^{\circ} \\
(0.03)\end{array}$ & $\begin{array}{l}-0.003 \\
(0.04)\end{array}$ & $\begin{array}{l}-0.03^{\circ} \\
(0.01)\end{array}$ \\
\hline $\begin{array}{l}\text { Change in Median } \\
\text { Earnings of Males Aged } \\
25+\end{array}$ & $\begin{array}{l}-0.03 \\
(0.02)\end{array}$ & $\begin{array}{l}-0.01 \\
(0.01)\end{array}$ & $\begin{array}{l}-0.03 \\
(0.02)\end{array}$ & $\begin{array}{l}-0.04^{*} \\
(0.02)\end{array}$ \\
\hline $\begin{array}{l}\text { Change in Percentage of } \\
\text { Population who are } \\
\text { Urban }\end{array}$ & $\begin{array}{c}0.17 \\
(0.09)\end{array}$ & $\begin{array}{l}0.02^{\circ} \\
(0.01)\end{array}$ & $\begin{array}{l}0.54^{-} \\
(0.14)\end{array}$ & $\begin{array}{l}0.000 \\
0.013\end{array}$ \\
\hline $\begin{array}{l}\text { Change in Number of } \\
\text { School Districts Per } \\
\text { Square Mile }\end{array}$ & $\begin{array}{l}1.71^{\circ} \\
(0.78)\end{array}$ & $\begin{array}{c}0.73 \\
(1.00)\end{array}$ & $\begin{array}{l}-5.76^{\circ} \\
(2.05)\end{array}$ & $\begin{array}{l}-1.42 \\
(4.68)\end{array}$ \\
\hline Constant & $\begin{array}{c}1.01 \\
(1.51)\end{array}$ & $\begin{array}{l}-2.79 \\
(1.71)\end{array}$ & $\begin{array}{l}-7.47^{-\infty} \\
(1.87)\end{array}$ & $\begin{array}{l}-3.70^{\circ} \\
(1.12)\end{array}$ \\
\hline No. of Observations & 49 & 49 & 49 & 49 \\
\hline R-Squared & 0.22 & 0.25 & 0.43 & 0.15 \\
\hline
\end{tabular}

standard errors in parentheses; " indicates that coefficient is significantly different trom zero at the 0.05 level of significance; - indicates that coefficient is significantly different from zero at the 0.01 level of significance.

Notes: observations are all U.S. states except Alaska (District of Columbia not included); weighted least squares estimates; all dollar amounts in $\$ 1990$.

sources: 1938-40, 1948-50, and 1958-60 Biennial Surveys of Education; 1972 and 1982 Censuses of Government; 1940 and 1950 Public Use Microdata Samples of the Census of Population; 1960, 1970, and 1980 summary tables of the Census of Population. 
Table 4

Effect on Teacher Salaries, Percentage of Teacher's Unionized, and Union Wage Gap of Change in State's Share of School Expenditure and Other Variables

\begin{tabular}{|c|c|c|c|}
\hline & $\begin{array}{l}\text { Percentage Change in } \\
\text { Average Teacher Salary }\end{array}$ & $\begin{array}{l}\text { Change in Pctage. of Teachers } \\
\text { under Collective Bargaining }\end{array}$ & $\begin{array}{l}\text { Change in Union Wage } \\
\text { Pctage. Gap (for Teachers) }\end{array}$ \\
\hline & 1980-70 Changes & 1980-70 Changes & 1980-70 Changes \\
\hline $\begin{array}{l}\text { Change in Percentage of } \\
\text { Public School Spending } \\
\text { Accounted tor by State }\end{array}$ & $\begin{array}{l}0.25^{\circ} \\
(0.10)\end{array}$ & $\begin{array}{l}1.40^{-} \\
(0.31)\end{array}$ & $\begin{array}{l}0.35^{*} \\
(0.17)\end{array}$ \\
\hline $\begin{array}{l}\text { Change in Median } \\
\text { Earnings of Males Aged } \\
25+\end{array}$ & $\begin{array}{l}0.52^{-} \\
(0.20)\end{array}$ & $\begin{array}{l}-1.08 \\
(0.61)\end{array}$ & $\begin{array}{c}0.06 \\
(0.40)\end{array}$ \\
\hline $\begin{array}{l}\text { Change in Percentage of } \\
\text { Population who are } \\
\text { Urban }\end{array}$ & $\begin{array}{c}0.13 \\
(0.09)\end{array}$ & $\begin{array}{l}0.17 \\
(0.29)\end{array}$ & $\begin{array}{l}-0.03 \\
(0.17)\end{array}$ \\
\hline $\begin{array}{l}\text { Change in Number of } \\
\text { School Districts Per } \\
\text { Square Mile }\end{array}$ & $\begin{array}{l}-0.30 \\
(0.34)\end{array}$ & $\begin{array}{l}-1.89^{*} \\
(1.04)\end{array}$ & $\begin{array}{c}0.12 \\
(0.53)\end{array}$ \\
\hline Constant & $\begin{array}{r}47.64^{-\infty} \\
(0.17)\end{array}$ & $\begin{array}{l}32.32 \\
(25.14)\end{array}$ & $\begin{array}{l}-0.04 \\
(0.15)\end{array}$ \\
\hline No. of Observations & 49 & 49 & 49 \\
\hline R-Squared & 0.38 & 0.35 & 0.09 \\
\hline
\end{tabular}

standard errors in parentheses: " indicates that coefficient is significantly different from zero at the 0.05 level of significance; - indicates that coefficient is significantly different from zero at the 0.01 level of significance.

Notes: observations are all U.S. states except Alaska (District of Columbia not included); weighted least squares estimates; all dollar amounts in $\$ 1990$.

sources: 1938-40, 1948-50, and 1958-60 Biennial Surveys of Education; 1972 and 1982 Censuses of Government; 1940 and 1950 Public Use Microdata Samples of the Census of Population; 1960, 1970, and 1980 summary tables of the Census of Population. 
Table 5

Effect on Educational Attainment of Change in State's Share of School Expenditure and Other ;ariables

\begin{tabular}{|c|c|c|c|c|}
\hline & \multicolumn{4}{|c|}{ Change in Percentage of Males Who Completed 4 Years of High Scho.: } \\
\hline & $\begin{array}{l}\text { Those Aged } 5-14 \text { in } \\
1940 \text { vs. Those } \\
\text { Aged } 5-14 \text { in } 1930\end{array}$ & $\begin{array}{l}\text { Those Aged } 5-14 \text { in } \\
1950 \text { vs. Those } \\
\text { Aged } 5-14 \text { in } 1940\end{array}$ & $\begin{array}{l}\text { Those Aged } 5-14 \text { in } \\
1960 \text { vs. Those } \\
\text { Aged } 5-14 \text { in } 1950\end{array}$ & $\begin{array}{l}\text { Those Aged } 5-14 \text { in } \\
1970 \text { vs. Those } \\
\text { Aged } 5-14 \text { in } 1960\end{array}$ \\
\hline & 1950-40 Changes & 1960-50 Changes & 1970-60 Changes & 1980-70 Changes \\
\hline $\begin{array}{l}\text { Change in Percentage of } \\
\text { Public School Spending } \\
\text { Accounted for by State }\end{array}$ & $\begin{array}{l}-0.05 \\
(0.04)\end{array}$ & $\begin{array}{l}-0.04^{\circ} \\
(0.02 j\end{array}$ & $\begin{array}{l}-0.02 \\
(0.02)\end{array}$ & $\begin{array}{c}-0.10^{\circ} \\
(0.02)\end{array}$ \\
\hline $\begin{array}{l}\text { Change in Median } \\
\text { Earnings of Males Aged } \\
25+\end{array}$ & $\begin{array}{l}0.04^{*} \\
(0.02)\end{array}$ & $\begin{array}{l}0.04^{\infty} \\
(0.01)\end{array}$ & $\begin{array}{c}0.01 \\
(0.01)\end{array}$ & $\begin{array}{c}0.04 \\
(0.05)\end{array}$ \\
\hline $\begin{array}{l}\text { Change in Percentage of } \\
\text { Population who are } \\
\text { Urban }\end{array}$ & $\begin{array}{l}-0.26^{*} \\
(0.11)\end{array}$ & $\begin{array}{l}0.03^{\infty} \\
(0.01)\end{array}$ & $\begin{array}{c}0.03 \\
(0.08)\end{array}$ & $\begin{array}{c}0.05^{*} \\
(0.02)\end{array}$ \\
\hline $\begin{array}{l}\text { Change in Number of } \\
\text { School Districts Per } 100 \\
\text { Square Miles }\end{array}$ & $\begin{array}{l}0.04^{\infty} \\
(0.01)\end{array}$ & $\begin{array}{l}-0.03^{-1} \\
(0.01)\end{array}$ & $\begin{array}{l}-0.01 \\
(0.01)\end{array}$ & $\begin{array}{c}0.11 \\
(0.08)\end{array}$ \\
\hline Constant & $\begin{array}{l}5.32^{\infty} \\
(1.67)\end{array}$ & $\begin{array}{l}5.04^{-} \\
(1.30)\end{array}$ & $\begin{array}{c}13.94^{\circ} \\
(1.05)\end{array}$ & $\begin{array}{c}12.21^{\star} \\
(1.92)\end{array}$ \\
\hline No. of Observations & 49 & 49 & 49 & 49 \\
\hline R-Squared & 0.42 & 0.50 & 0.03 & 0.4 . \\
\hline
\end{tabular}

standard errors in parentheses; ${ }^{\bullet}$ indicates that coefficient is significantly different from zero at the 0.05 level of significance; - indicates that coefficient is significantly different from zero at the 0.01 level of significance.

Notes: observations are all U.S. states except Alaska (District of Columbia not included); weighted least squares estimates; all dollar amounts in \$1990; males aged 5-14 in 1940 were aged 25-34 in the 1960 Census et cetera. In each case (except 1930). data were drawn from Census in which males were aged 25-34.

sources: $1938-40,1948-50$, and 1958-60 Biennial Surveys of Education; 1972 and 1982 Censuses of Govemment; 1940 and 1950 Public Use Microdata Samples of the Census of Population; 1960, 1970, and 1980 summary tables of the Census of Population. 
Appendix Table 1

Descriptive Statistics

\begin{tabular}{|c|c|c|}
\hline & Mean & Standard Deviation \\
\hline 1940 Percentage of School Spending Accounted for by State & 30.5 & 21.9 \\
\hline 1950 Percentage of School Speniz...g Accounted for by State & 41.7 & 22.1 \\
\hline 1960 Percentage of School Spendug Accounted for by State & 39.5 & 18.9 \\
\hline 1970 Percentage of School Spetuding Accounted for by State & 51.0 & 17.7 \\
\hline 1980 Percentage of School Spending Accounted for by State & 55.5 & 21.2 \\
\hline 1940 Per-Pupil Expenditure $(\$ 1990)$ & 748 & 267 \\
\hline 1950 Per-Pupil Expenditure $(\$ 1990)$ & 1073 & 268 \\
\hline 1960 Per-Pupi: Expenditure $(\$ 1990)$ & 1365 & 361 \\
\hline 1970 Per-Pupil Expenditure $(\$ 1990)$ & 2676 & 583 \\
\hline 1980 Per-Pupil Expenditure (\$1990) & 3606 & 796 \\
\hline 1940 Student-Teacher Ratio & 28.5 & 4.8 \\
\hline 1950 Student-Teacher Ratio & 26.8 & 3.9 \\
\hline 1960 Student-Teacher Ratio & 26.6 & 3.3 \\
\hline 1970 Student-Teacher Ratio & 18.9 & 1.8 \\
\hline 1980 Student-Teacher Ratio & 14.7 & 1.9 \\
\hline 1970 Average Teacher Salary $(\$ 1990)$ & 32666 & 5810 \\
\hline 1980 Average Teacher Salary $(\$ 1990)$ & 30503 & 5426 \\
\hline 1970 Percentage of Teachers Under Collective Bargaining & 39 & 30 \\
\hline 1980 Percentage of Teachers Under Collective Bargaining & 58 & 34 \\
\hline 1970 Union Wage Gap in Percent (for Teachers) & 5.5 & 10.2 \\
\hline 1980 Union Wage Gap in Percent (for Teachers) & 9.0 & 10.0 \\
\hline Pct. who Completed 4 Yrs of High School, Males Aged 5-9 in 1930 & 36.1 & 7.0 \\
\hline Pet. who Completed 4 Yrs of High School, All Aged 5-9 in 1940 & 41.8 & 7.3 \\
\hline Pct. who Completed 4 Yrs of High School, All Aged 5-9 in 1950 & 53.1 & 8.0 \\
\hline Pct. who Completed 4 Yrs of High School, All Aged 5-9 in 1960 & 67.5 & 7.5 \\
\hline Pct. who Completed 4 Yrs of High School, All Aged 5-9 in 1970 & 76.2 & 5.6 \\
\hline
\end{tabular}

All variables are measured at the state level and have 49 observations.

Note that males aged 5-9 in 1930 were aged 25-29 in the 1950 Census et cetera. In each case, data were drawn from Census in which people were aged $25-29$.

This table is continued on the next page 
Appendix Table 1 Continued

Descriptive Statistics

\begin{tabular}{|c|c|c|}
\hline & Mean & Standard Deviation \\
\hline 1940 Median Earnings of Males Aged $25+$ who Have Earnings & 5392 & 1611 \\
\hline 1950 Median Earnings of Males Aged $25+$ who Have Earnings & 8661 & 1933 \\
\hline 1960 Median Earnings of Males Aged $25+$ who Have Eamings & 16148 & 3423 \\
\hline 1970 Median Earnings of Males Aged $25+$ who Have Earnings & 28747 & 4603 \\
\hline 1980 Median Eamings of Males Aged $25+$ who Have Eamings & 32563 & 4469 \\
\hline 1940 Percentage of Population who are Urban & 39.6 & 28.6 \\
\hline 1950 Percentage of Population who are Urban & 43.2 & 28.2 \\
\hline 1960 Percentage of Population who are Urban & 62.5 & 15.8 \\
\hline 1970 Percentage of Population who are Urban & 66.5 & 15.1 \\
\hline 1980 Percentage of Population who are Urban & 67.8 & 15.0 \\
\hline 1940 Number of School Districts Per 100 Square Miles & 0.42 & 0.47 \\
\hline 1950 Number of School Districts Per 100 Square Miles & 0.33 & 0.33 \\
\hline 1960 Number of School Districts Per 100 ¿quare Miles & 0.21 & 0.20 \\
\hline 1970 Number of School Districts Per 100 Square Miles & 0.09 & 0.11 \\
\hline 1980 Number of School Districts Per 100 Square Miles & 0.09 & 0.13 \\
\hline
\end{tabular}

All variables are measured at the state level and have 49 observations.

Appendix Table 2 contains descriptive statistics on the changes in the variables shown in Appendix Table 1. 
Appendix Table 2

Descriptive Statistics of Changes in Variables

\begin{tabular}{|c|c|c|}
\hline & Mean & Standard Deviation \\
\hline 1950-40 Change in Percentage of School Spending Accounted for by State & 11.2 & 8.2 \\
\hline 1960-50 Change in Percentage of School. & -2.3 & 7.3 \\
\hline 1970-60 Change in Percentage of School Spending Accounted for by State & 12.0 & 11.3 \\
\hline 1980-70 Change in Percentage of School Spending Accounted for by State & 6.4 & 11.9 \\
\hline 1950-40 Percentage Change in Per-Pupil Expenditure & 52.2 & 25.8 \\
\hline 1960-50 Percentage Change in Per-r'rupil Expenditure & 31.1 & 12.5 \\
\hline 1970-60 Percentage Change in Per-Pupil Expenditure & 92.1 & 22.2 \\
\hline 1980-70 Percentage Change in Per-Pupil Expenditure & 35.1 & 15.4 \\
\hline $1950-40$ Change in Student-Teacher Ratio & -1.7 & 2.0 \\
\hline 1960-50 Change in Student-Teacher Ratio & -0.2 & 1.7 \\
\hline 1970-60 Change in Student-Teacher Ratio & -7.6 & 2.6 \\
\hline 1980-70 Change in Student-Teacher Ratio & -4.2 & 1.1 \\
\hline 1970-60 Percentage Change in Average Teacher Salary & -13.3 & 21.8 \\
\hline 1980-70 Change in Percentage of Teachers Under Collective Bargaining & 18.4 & 25.4 \\
\hline 1980-70 Change in Percent Union Wage Gap (for Teachers) & 3.6 & 14.8 \\
\hline $\begin{array}{l}\text { Change in Pct. who Completed } 4 \text { Yrs of High School, Aged 5-9 in } 1940 \text { vs. } \\
\text { Aged 5-9 in } 1930\end{array}$ & 5.3 & 3.2 \\
\hline $\begin{array}{l}\text { Change in Pct. who Completed } 4 \text { Yrs of High School, Aged 5-9 in } 1950 \text { vs. } \\
\text { Aged 5-9 in } 1940\end{array}$ & 11.3 & 1.7 \\
\hline $\begin{array}{l}\text { Change in Pct. who Completed } 4 \text { Yrs of High School, Aged 5-9 in } 1960 \text { vs. } \\
\text { Aged 5-9 in } 1950\end{array}$ & 14.3 & 1.2 \\
\hline $\begin{array}{l}\text { Change in Pct. who Completed } 4 \text { Yrs of High School, Aged 5-9 in } 1970 \text { vs. } \\
\text { Aged 5-9 in } 1960\end{array}$ & 8.8 & 2.7 \\
\hline
\end{tabular}

All variables are measured at the state level and have 49 observations.

Note that males aged 5-9 in 1930 were aged 25-29 in the 1950 Census et cetera. In each case, data were drawn from Census in which people were aged $25-29$.

This table is continued on the next page 
Appendix Table 2 Continued Descriptive Statistics of Changes in Variables

\begin{tabular}{|c|c|c|}
\hline & Mean & Standard Deviation \\
\hline 1950-40 Pctage Change in Median Earnings of Males Aged $25+w /$ Earnings & 65.0 & 18.4 \\
\hline 1960-50 Pctage Change in Median Earnings of Males Aged $25+w /$ Eamings & 87.4 & 19.9 \\
\hline 1970-60 Pctage Change in Median Earnings of Males Aged $25+w /$ Earnings & 81.7 & 24.3 \\
\hline 1980-70 Pctage Change in Median Earnings of Males Aged $25+w /$ Earnings & 13.9 & 7.3 \\
\hline $1950-40$ Change in Percentage of Population who are Urban & 3.6 & 3.4 \\
\hline 1960-50 Change in Percentage of Population who are Urban & 19.4 & 17.3 \\
\hline 1970-60 Change in Percentage of Population who are Urban & 3.9 & 3.3 \\
\hline 1980-70 Change in Percentage of Population who are Urban & 1.1 & 3.1 \\
\hline $1950-40$ Change in Number of School Districts Per 100 Square Miles & -0.09 & 0.23 \\
\hline 1960-50 Change in Number of School Districts Per 100 Square Miles & -0.12 & 0.19 \\
\hline 1970-60 Change in Number of School Districts Per 100 Square Miles & -0.13 & 0.16 \\
\hline 1980-70 Change in Number of School Districts Per 100 Square Miles & 0.02 & 0.09 \\
\hline
\end{tabular}

All variables are measured at the state level and have 49 observations. 


\section{Data Appendix}

Public School Finance Programs, 1971-72 and 1978-79

Public School Finance Programs of the United States and Canada. 1986-87

These books describe state and local funding formulae and taxes for public schools by U.S. state. The first two books listed above were published by the Office of Education of the U.S. Department of Health. Education, and Welfare. The third book listed was published by the American Education Finance Association.

Biennial Surveys of Education, 1938-40, 1948-50, 1958-60

These books contain statistics and description of public and private schools by U.S. state. Variables taken (with no modification) from the Surveys are: state shares of spending. per-pupil spending. student-teacher ratios. number of school districts.

Censuses of Governments, 1972 and 1982

The Census of Governments surveys every school district in the U.S. The data include information on enrollment, teachers. teachers' payroll, collective bargaining, sources of revenue, and expenditure. Note that unionization is derined to be collective bargaining in this paper to avoid confounding teachers' unions with teachers' organizations that do not perform union duties. See Hoxby "Teachers' Unions and the Effectiveness of Policies Designed to Improve School Quality," Harvard University mimeo. Average teacher salary is average salary for a full-time teacher. Student-teacher ratio is the ratio of full-time-equivalent instructional personnel to enrollment. This is not intended to be identical to class size, as the student-teacher ratio is better as a measure of cost. The union wage gap is the difference between the average unionized teacher's wage and the average nonunionized teacher's wage in a state.

Public Use Microdata Samples (PUMS) of the Census of Population, 1940 and 1950

The 1940 Census of Population was the first to survey educational attainment. Only males are used from these PUMS. Variables derived are: median earnings of males aged 25 plus (who have eamings), percentage of the male population residing in urban areas, percentage of males aged 24-29 who have completed 4 years of high school.

Summary Tables of the Census of Population, 1960, 1970, and 1980

Variables derived are: median earnings of males aged 25 plus (who have earnings). percentage of the population residing in urban areas, percentage aged 24-29 who have completed 4 years of high school. 